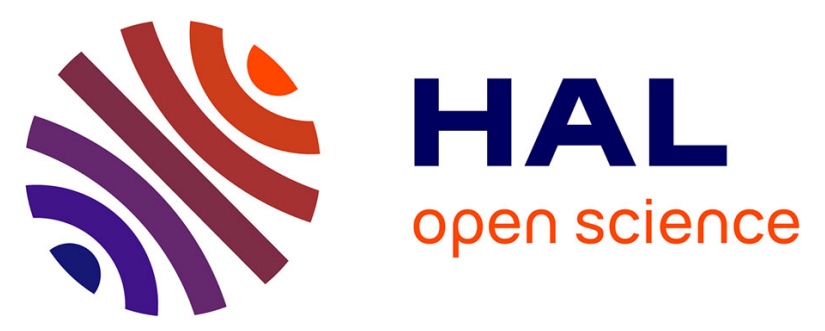

\title{
New insights on the interpretation of alum-based fake silver recipes from 3rd century CE by an experimental archaeology approach in the laboratory
}

\author{
E. Ferrari, F. Mercier, E. Foy, Florian Téreygeol
}

\section{- To cite this version:}

E. Ferrari, F. Mercier, E. Foy, Florian Téreygeol. New insights on the interpretation of alum-based fake silver recipes from 3rd century CE by an experimental archaeology approach in the laboratory. Journal of Archaeological Science: Reports, 2021, 36, pp.102742. 10.1016/j.jasrep.2020.102742 . hal03345433

\author{
HAL Id: hal-03345433 \\ https://hal.science/hal-03345433
}

Submitted on 28 Sep 2021

HAL is a multi-disciplinary open access archive for the deposit and dissemination of scientific research documents, whether they are published or not. The documents may come from teaching and research institutions in France or abroad, or from public or private research centers.
L'archive ouverte pluridisciplinaire HAL, est destinée au dépôt et à la diffusion de documents scientifiques de niveau recherche, publiés ou non, émanant des établissements d'enseignement et de recherche français ou étrangers, des laboratoires publics ou privés. 
New insights on the interpretation of alum-based fake silver recipes from $3^{\text {rd }}$ century AD by an experimental archaeology approach in the laboratory

E. Ferrari ${ }^{1 *}$, F. Mercier*, E. Foy*, F. Téreygeol*

*Laboratoire Archéomatériaux et Prévision de l'Altération (LAPA) - Université Paris-Saclay, CEA, CNRS, NIMBE, Saclay, Bâtiment 637, 91191 Gif-sur-Yvette Cedex, France

${ }^{1}$ Corresponding author

\section{Abstract}

Experimental archaeology was first theorised by Ascher in 1961 and then by Coles in 1973: it represents an important research methodology for the study of ancient technologies and societies. Since the 1990's of the last century, the new concept of 'experimental archaeometry' appears in the wider field of archaeological science. Following this approach, two alchemical recipes from a $3^{\text {rd }}$ century $\mathrm{AD}$ papyrus were reproduced in the laboratory. In this paper, a link between archaeometry and experimental archaeology is established, and a re-interpretation of the original recipes is proposed.

Keywords

Ancient metallurgy, alum, doubling silver, archaeometry, experimental archaeology

\section{Introduction $^{1}$}

Alum rarely appears in the field of metallurgy (Giumla-Mair, 2005). The collection of texts that goes under the name of papyri of Leiden and Stockholm (Halleux, 1981) represent an important exception. In the documents, dating back to the $3^{\text {rd }}$ century $\mathrm{AD}$, the term 'alum' appears 15 times, which makes it the most common additive in the metallurgical recipes described. As archaeological finds are concerned, it remains challenging to prove whether alum is used as finishing or during the alloying process. The question arises as to how it is possible to link historical sources with objects from archaeological excavations concerning the use of such an elusive material. One possible way is the experimental approach. In this paper, we aim at reproducing ancient recipes in the laboratory.

\footnotetext{
${ }^{1}$ This paper is part of a Special Issue on the Contributions of Experimental Archaeology to Excavation and Material Studies, guest edited by Frederik W. Rademakers, Georges Verly, Florian Téreygeol and Johannes Auenmüller.
} 
This approach might be relatively simple when dealing with technical texts from the Renaissance period while several problems arise in the case of older metallurgical and alchemical recipes. First, it is unclear whether the person who writes is himself an artisan. Secondly, the document we read is a translation into a modern language, meaning the translator already did an interpretation of the text. Indeed the actual limitation when applying an experimental approach to this type of documents is our interpretation. The researcher might decide to exclude certain actions or materials for which one does not understand the purpose: this may reflect negatively on the outcomes of the study. At the same time, we should be able to identify what is confusing and, in our modern view, pointless.

\section{Aim of the study}

In this study, we aim at replicating the processes to obtain 'edulcorated' silver when mixing copper oxides (in form of copper scale) with silver as described in the papyri of Leiden and Stockholm.

In a copper-rich silver alloy, up to $85 \%$ in mass of copper can be present without a considerable change in the aesthetical properties of the final product compared to pure silver. ${ }^{2}$ The alloying process can highly reduce the cost of the final artefact but it can be also interpreted as a fraud. In the ancient texts considered here, the use of a by-product of copper production, the copper scale is reported. The copper scale corresponds to the oxide particles, often in form of platelets, that are detached from the metal as hammering is applied during the annealing process. In the described recipes, such particles are never used as such, but, before being added to silver for melting, they undergo a pre-treatment in an alum-containing bath. This is possibly related to the intention of producing a silvery-looking material that would be added to silver during the casting.

\section{Corpus of the study}

The present study is based on two recipes reported in the papyri of Leiden and Stockholm. In both described processes a copper scale undergoes a 'pre-treatment' using a solution containing alum and, afterwards, it is melted with silver. These texts were identified in 1830 and a first description can be found in (Berthelot, 1889). In his edition, Robert Halleux provides all the specific information for these documents (Halleux, 1981, 5-78).

\footnotetext{
${ }^{2}$ Mechanical properties of the alloy improve compared to pure silver.
} 
We report the text \#6 as found in the papyri of Leiden and Stockholm (English translation from Halleux, 1981, page 111):

\section{Holm 6 «Other » [doubling silver]}

Immerse the copper scale in a brine and soak for 6 days in alum and shiny earth dissolved in fresh water. Then melt by adding silver.

The recipe is very short. According to the interpretation of Robert Halleux (Halleux, 1981, page 111, note 9), the process is carried out in two stages, followed by a melt. The first step consists in dipping the copper scale in an unspecified brine. In the second step, the scale is plunged into a second bath of alum and "shiny earth". Robert Halleux proposes a parallel with recipe \#12 in the papyrus of Leiden ${ }^{3}$

Leid 12 «Production of Asem » (i.e. silver alloy, see Halleux, 1973)

Take the copper scale, soak in vinegar and lamellar white alum and soak for 7 days, then melt with a quarter of copper, 8 of earth of Chio, 8 of Samos earth drachmas, 1 of Cappadocian salt, 1 of lamellar alum. Mix and melt by adding Adramyttion silver. (Halleux, 1981, p. 87).

In this latter recipe, the binary rhythm of the work is clearly stated. The second step which consists in including the earthy elements and which is described here as a cast, can only be a chemical treatment in solution: this might be an indication of the fact that the writer of the recipe is not fully acquainted with the metallurgical work. In addition, unlike the first, this second recipe promotes the use of vinegar as a reactive element.

From reading both recipes, the interpretation of them leads to several questions:

1. Are we dealing with a forgery recipe?

2. What is the role of the alum solution bath?

3. Which is the most efficient way to obtain the desired effect (whitening of the scale surface)?

4. What is the meaning of working with copper scale to produce a copper-silver alloy?

\footnotetext{
${ }^{3}$ This observation seems consistent considering the fact that the two recipes were originally part of the same collection of texts and they were separated after their discovery (Halleux, 1981).
} 
In order to answer these questions, we set up an open experimental plan following on one side the process described in the texts stricto sensu (apart from the supposed cast in Leid 12) and, on the other side, the interpretation suggested by Robert Halleux for the Holm 6 text. Our approach focuses on the 'pre-treatment' of copper scale. Finally, a comparative test is carried out by melting the treated scale with silver. Both the raw materials and the products obtained from the different experiments are characterized using a multi-analytical approach.

\section{Materials and methods}

Choice of raw materials

In order to follow the processes described above in the most accurate way, it is necessary to employ materials, which we do not usually find in a chemistry lab.

Sea salt, vinegar and alum are employed without any further purification. Drinking water $\left(\mathrm{pH}=7.5\right.$ at $\left.20^{\circ} \mathrm{C}\right)$ is used instead of the deionized one. The role of the different earths cited in the ancient texts is not investigated here as we suppose it not to be of primary importance for the whole process.

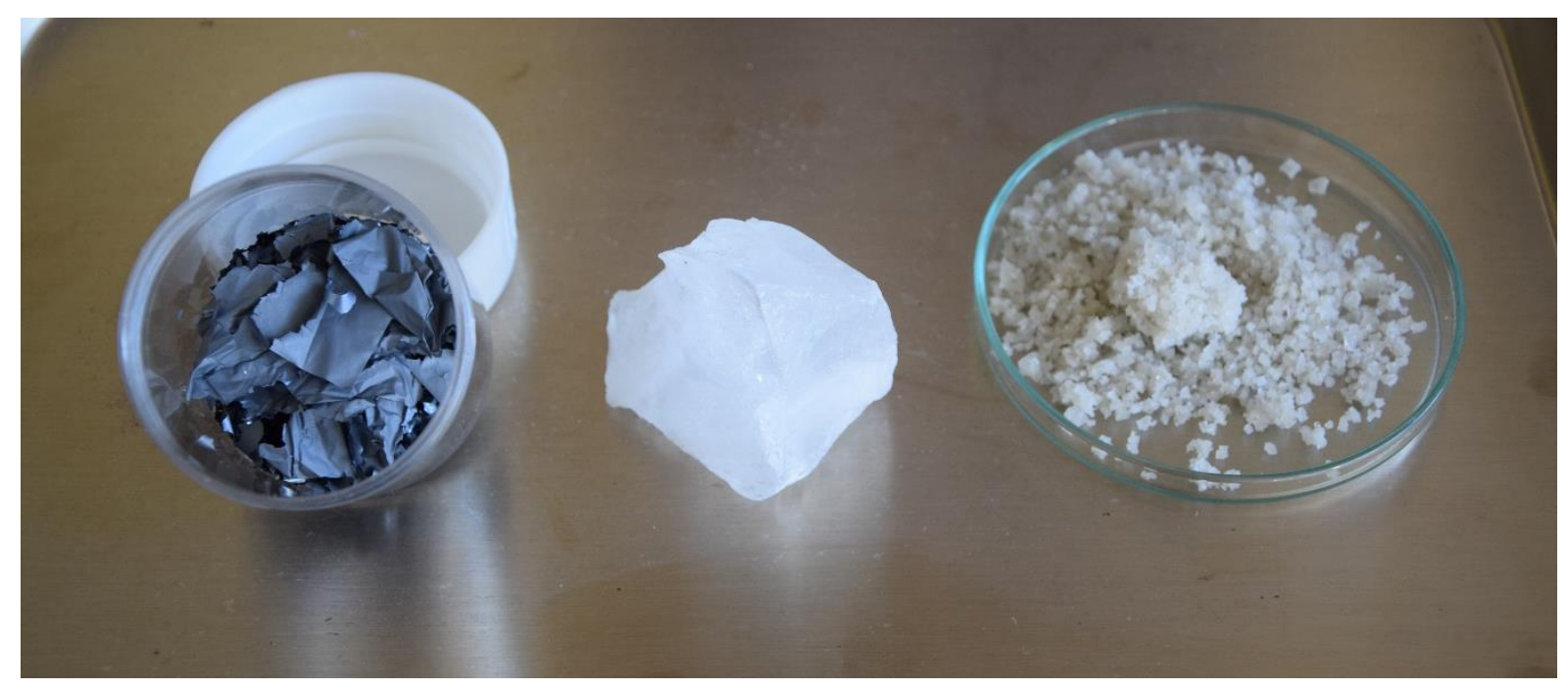

Figure 1. Raw materials, from left to right: copper scale, alum and sea salt.

Sea salt: unrefined sea salt is employed. Main component is $\mathrm{NaCl}$.

Vinegar: red wine $\left(6^{\circ}\right)$ vinegar is employed. Measured $\mathrm{pH}$ at $20^{\circ} \mathrm{C}$ is 2.9 . 
Copper scale: copper scale is generally obtained by delamination of the oxide layer during hot-working of copper. The one employed in this study is produced by heating at $900^{\circ} \mathrm{C} \mathrm{a}$ copper foil (99\%, Alfa Aesar) of ca. $25 \mu \mathrm{m}$ thickness. The atmosphere in the oven is not controlled and a natural ventilation is provided. After 2 hours, the foil is completely transformed: it appears black and brittle. Diffraction and Raman analysis are performed on the scale in order to determine its composition and are presented in the Results section. Synthetic cuprite (97\%, Sigma-Aldrich) is employed in one of the experiments.

\section{Alum}

A natural crystal of alum retrieved from a drugstore in Yemen is employed (Figure 1). The exact crystallographic identification is presented in the Results section. Some considerations about this material are necessary. As Maurice Picon pointed out in the occasion of the conference on alum in the Mediterranean basin (Borgard et al, 2005), various natural, artificial and synthetic materials can be ascribed to the term 'alum'. Among the artificial alum, meaning the one produced by transforming the mineral, we can find potassium or ammonium alum $\left(\left(\mathrm{NH}_{4}\right) \mathrm{Al}\left(\mathrm{SO}_{4}\right)_{2} \cdot 12 \mathrm{H}_{2} \mathrm{O}\right)$.

Natural alums are hydrated double salts of aluminium sulphate and another cation; the most common being halotrichite $\left(\mathrm{FeAl}_{2}\left(\mathrm{SO}_{4}\right)_{4} \cdot 22 \mathrm{H}_{2} \mathrm{O}\right)$, pickeringite $\left(\mathrm{MgAl}_{2}\left(\mathrm{SO}_{4}\right)_{4} \cdot 22 \mathrm{H}_{2} \mathrm{O}\right)$ and alunite $\left(\mathrm{KAl}_{3}\left(\mathrm{SO}_{4}\right)_{2}(\mathrm{OH})_{6}\right)$. In order to be employed, they undergo a simple handpicking, while more complex production process is required to obtain artificial alum from alunite or, more recently, from pyritic schist.

Experimental plan

\section{Pre-treatment of the copper scale: choice of the procedure}

The interpretation of the texts mentioned above lead to the set-up of several recipes selected for the experimentation.

The 'pre-treatment' solutions are reported here: 
- Solution 1 ("sol.1") is prepared by dissolving alum in $10 \mathrm{~mL}$ water until saturation is reached. $10 \mathrm{~mL}$ of vinegar are added to the solution. Final $\mathrm{pH}$ is 2.5 at $20^{\circ} \mathrm{C}$.

- Solution 2 ("sol.2") is prepared by dissolving alum in $20 \mathrm{~mL}$ water until saturation is reached. Final $\mathrm{pH}$ is 3.2 at $20^{\circ} \mathrm{C}$.

- Solution 3 ("sol.3") is prepared by dissolving sea salt in $20 \mathrm{~mL}$ water until saturation is reached. Final $\mathrm{pH}$ is 7.3 at $20^{\circ} \mathrm{C}$.

- Solution 4 ("sol.4") was prepared by mixing $10 \mathrm{~mL}$ alum-saturated solution in $10 \mathrm{~mL}$ sea salt-saturated solution. Final $\mathrm{pH}$ is 2.9 at $20^{\circ} \mathrm{C}$.

\section{Leid 12 : 'Two-steps procedure'}

Step 1: $1 \mathrm{~g}$ of copper scale is immersed for 7 days $^{4}$ in sol.1 (alum-vinegar). After 7 days, a first sampling is made on the scale.

Step 2: sol.1 is eliminated and the scale is immersed in sol.4 (salt-alum) for other 7 days. The scale is air dried and analysed.

\section{Leid 12 : 'One-step procedure'}

$1 \mathrm{~g}$ of copper scale is immersed for 7 days in sol.2 (alum). No rinsing and no drying are employed.

\section{Holm 6 : 'Two-steps procedure'}

${ }^{4} 7$ days is the immersion time adopted for all the recipes based on Leid 12. 
Step 1: $1 \mathrm{~g}$ of copper scale is immersed for 7 days in sol.3 (salt). After 7 days, one part of the scale (sample 3a) is air dried without rinsing. The other part (sample $3 b$ ) is rinsed with water and air dried.

Step 2: Sample 3a and 3b are immersed separately in sol.2 (alum) for 7 days. The scale is air dried and analysed.

\section{Holm 6 : 'One-step procedure'}

$1 \mathrm{~g}$ of copper scale is immersed for 7 days in sol.4 (salt-alum). In this case, different processes are applied after immersion:

- No rinsing and no oven drying: sample 4a

- 3 times water rinsing followed by air drying: sample $4 \mathrm{~b}$

- 1 time water rinsing followed by air drying: sample 4c

\section{Holm 6: 'synthetic cuprite'}

$1 \mathrm{~g}$ of synthetic $\mathrm{Cu}_{2} \mathrm{O}$ is immersed for 14 days in "sol. 4": sample 5.

\section{Melting operations}

After the first phase, two melting experiments were realised. Each was performed in an electric oven at $\mathrm{T}=1000^{\circ} \mathrm{C}$ for 15 minutes in a ceramic crucible. $1 \mathrm{~g}$ of silver and $0.2 \mathrm{~g}$ of copper scale are employed.

In one case, copper scale without any pre-treatment is added and in the second case, the pretreated copper scale 'sample $4 \mathrm{~b}$ ' was employed for the melting. We base our choice on the fact that the sample undergoes a change in colour comparable to the one described in the reference texts. 


\section{Characterization techniques}

Different analytical techniques are employed for the characterization of both the raw materials and the materials obtained with the experimental study.

X-Ray Diffraction (XRD) analysis is carried out using a Rigaku RU200 diffractometer equipped with a Mo X-Ray tube. An acceleration voltage of $55 \mathrm{kV}$ and a current of $21 \mathrm{~mA}$ are used. The monochromatic and focalized beam has an energy corresponding to $17.5 \mathrm{keV}$ and a surface of $100 \times 100 \mu \mathrm{m}^{2}$. The sample is irradiated by a flux in the order of $20 \cdot 10^{6}$ photons/s. Diffraction images are collected on photosensitive screens and diffraction patterns are elaborated using the software Fit2D (ESFR). The identification of the phases is made using the software DiffracEVA (Bruker AXS) with reference to the X-Ray diffraction database of the International Centre for Diffraction Data (ICDD).

Using the same apparatus, X-Ray Fluorescence (XRF) spectra are obtained through a SDD detector with an active area of $10 \mathrm{~mm}^{2}$ and then analyzed thanks to the PyMca software (Solé et al., 2007).

For the Raman spectrosocpy, a Renishaw ${ }^{\circledR}$ Invia Reflex $\mu$-spectrometer is employed. It is equipped with a 532nm Nd:YAG laser and an optical microscope. The surface analyzed is of about $1 \mu \mathrm{m}^{2}$. Calibration is made via a Silicon wafer with a Raman band at $520.5 \mathrm{~cm}^{-1}$. The spectra are collected using a 50X objective; the energy used was 5 to $1 \%$ of laser power corresponding to 1 to $0.1 \mathrm{~mW}$. Raman spectra have a resolution of $2 \mathrm{~cm}^{-1}$ and are processed using the software Wire3.4. They are presented here without baseline correction.

\section{Results}

Characterization of raw materials: copper scale and natural alum

Figure 2 shows the $\mathrm{X}$-ray diffraction pattern of the copper scale. Two copper oxide are identified cuprite $\left(\mathrm{Cu}_{2} \mathrm{O}\right)$ and tenorite $(\mathrm{CuO})$ are equally present. 


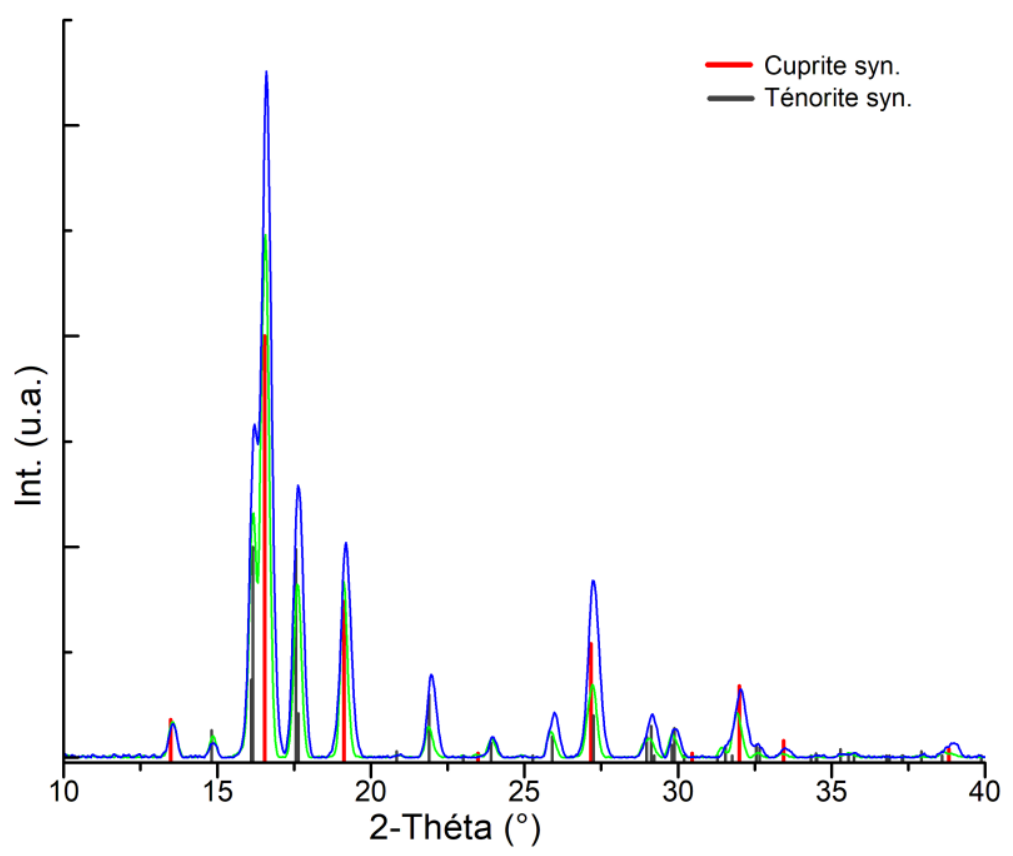

Figure 2: Diffraction pattern of the copper scale obtained after heating in the muffle furnace. The scale as it appears after heating (green) and the scale grinded (blue). In red, the characteristic signature of cuprite $\left(\mathrm{Cu}_{2} \mathrm{O}\right)$, and in black that of tenorite (CuO).

The presence of both copper oxides derives from the lack of control on the atmosphere during heating. Optical microscope observations point out the two different appearances of the copper scale: one side appears shiny while the other is matte. The difference is highlighted when performing Raman spectroscopy on both sides of the copper scale sheet (Figure 3). 


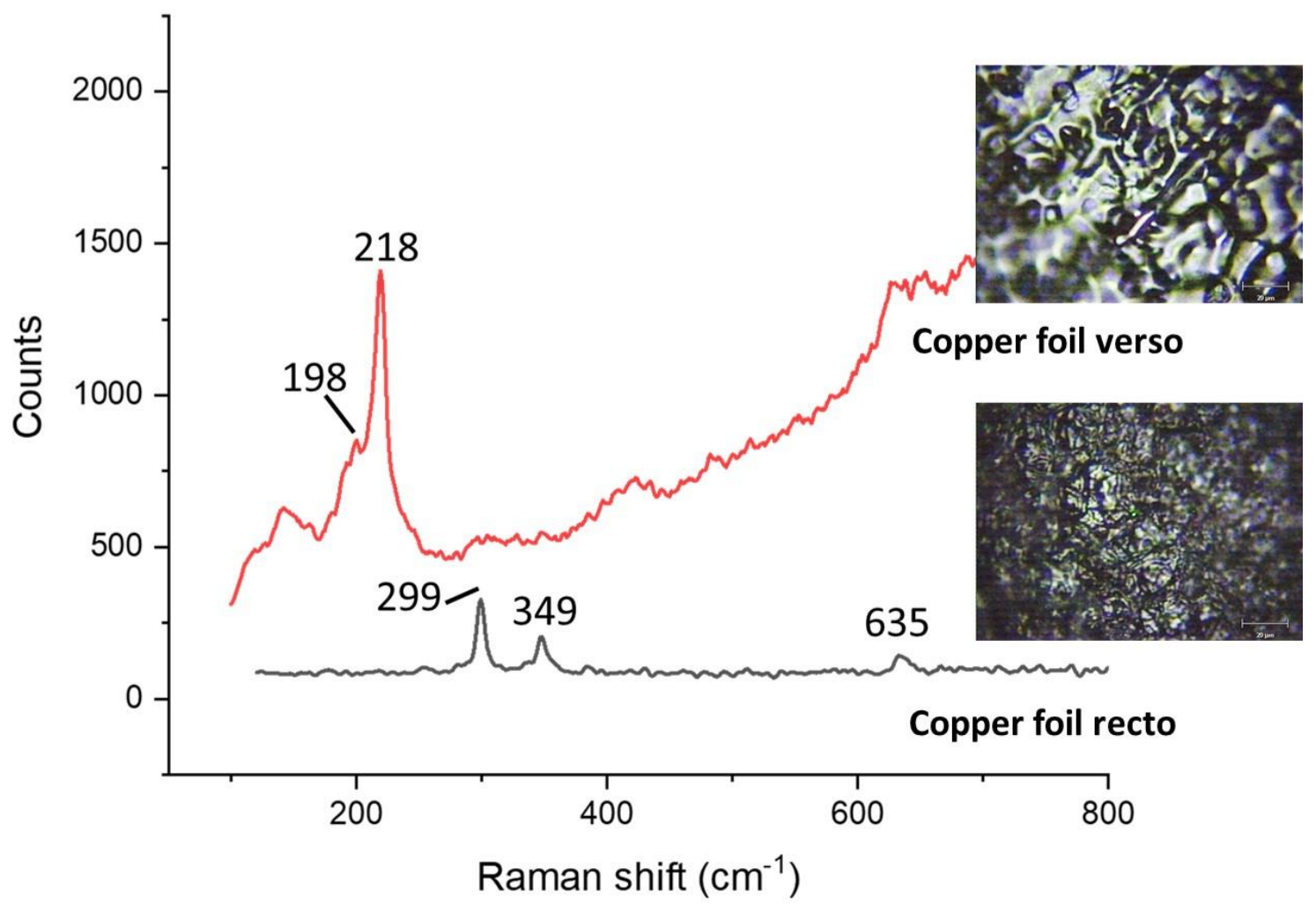

Figure 3: Raman spectra of the copper scale.

On one side (recto), the signature of tenorite is identified by the bands at 299,349 and $635 \mathrm{~cm}^{-}$

1 (Deng et al, 2016); on the other side (verso), the characteristic shifts of cuprite are identified $\left(218,198 \mathrm{~cm}^{-1}\right)$ (Bouchard et al. 2003).

The identification of both cuprous and cupric oxides in the scale leads to the conclusion that the material obtained is similar to the one obtained by the smith during annealing and hammering operations. It consists of small sheets of copper oxide whose composition is subjected to the variability of ventilation and temperature that characterize the traditional fireplace.

The alum used for this experimentation is analyzed. XRF analysis coupled with XRD analysis allow to classify it as a potassium-based alum (Figure 4); other trace elements such as of Zn, $\mathrm{Pb}$ and $\mathrm{Cu}$ are detected. By performing XRD analysis, the presence of quartz is highlighted: both quartz and the trace elements are a clear indication that the sample is of natural origin. 


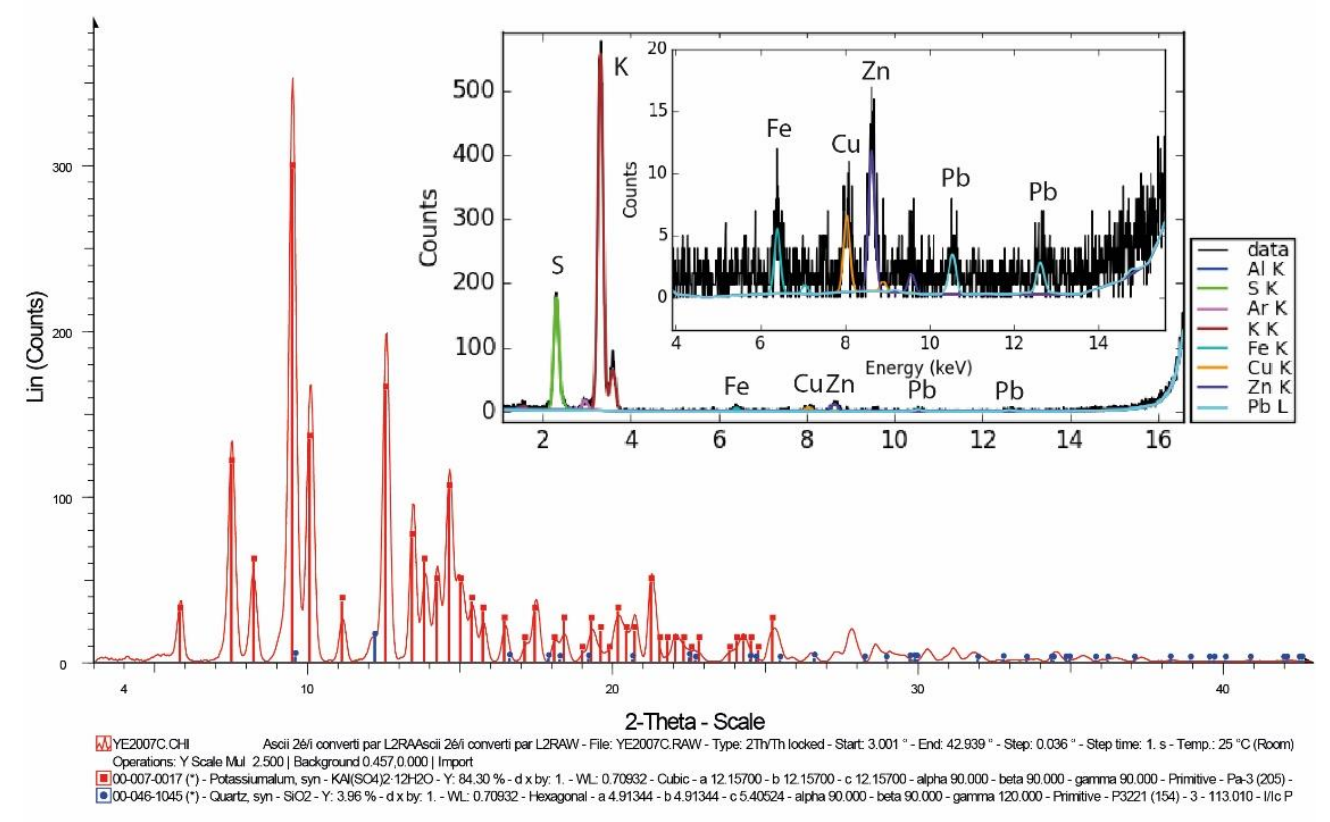

Figure 4: XRD analysis and X-ray fluorescence spectra of the alum crystal (the peaks of $\mathrm{Cu}, \mathrm{Zn}$ and $\mathrm{Pb}$ are highlighted in the upright panel.

Figure 5 shows the Raman spectrum of the alum crystal. The signature is characteristic of potassium alum (Kishimura et al., 2015). Main shifts are: an intense band at $989 \mathrm{~cm}^{-1}$, a broad band as doublet at 450 and $618 \mathrm{~cm}^{-1}$. The doublet at 1096 and $1133 \mathrm{~cm}^{-1}$ is also observed, as well as the weak band at $326 \mathrm{~cm}^{-1}$. 


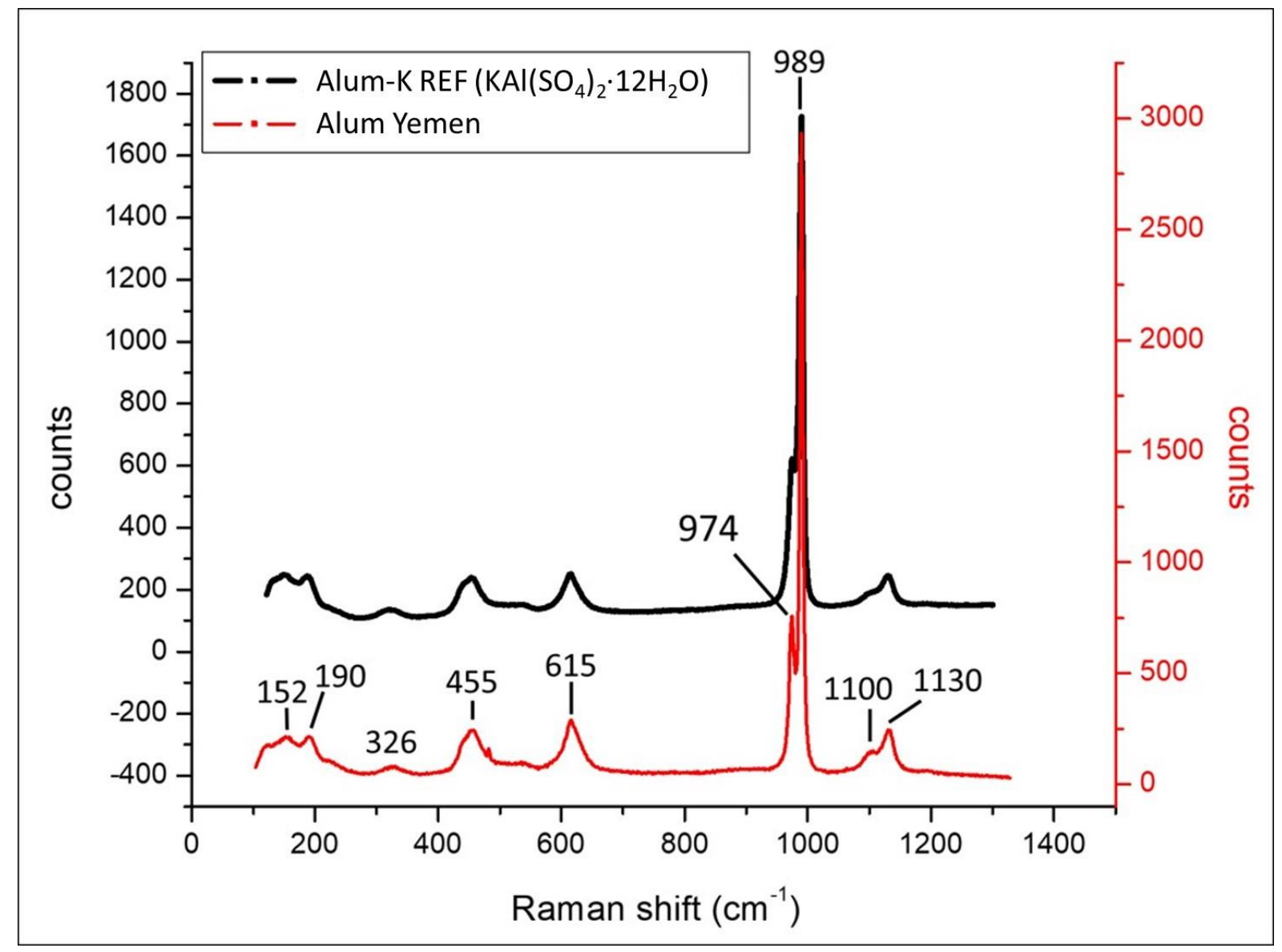

Figure 5: Raman spectra of the alum crystal (red) and of a specimen of alum-K (RRUFF ID: R040134.2).

\section{Results of the different processes before melting}

With the exception of sample 5, all the experiments produce a change in color of the copper scale. The surface structural characterization by Raman analysis shows that immersion in the different solutions induces the deposition of a whitish layer of alum on the surface of the otherwise black-red scale.

In Figure 6, the Raman spectra corresponding to the different samples are reported. In samples $1,2,4 \mathrm{a}, 4 \mathrm{~b}$ and $4 \mathrm{c}$, potassium alum is detected as major component. In sample $4 \mathrm{a}$, cuprite is also detected (by the $219 \mathrm{~cm}^{-1}$ pick) as minor component. In samples $3 \mathrm{a}$ and $3 \mathrm{~b}$, tenorite is detected as the major component, although some alum seems to be present on the surface. 

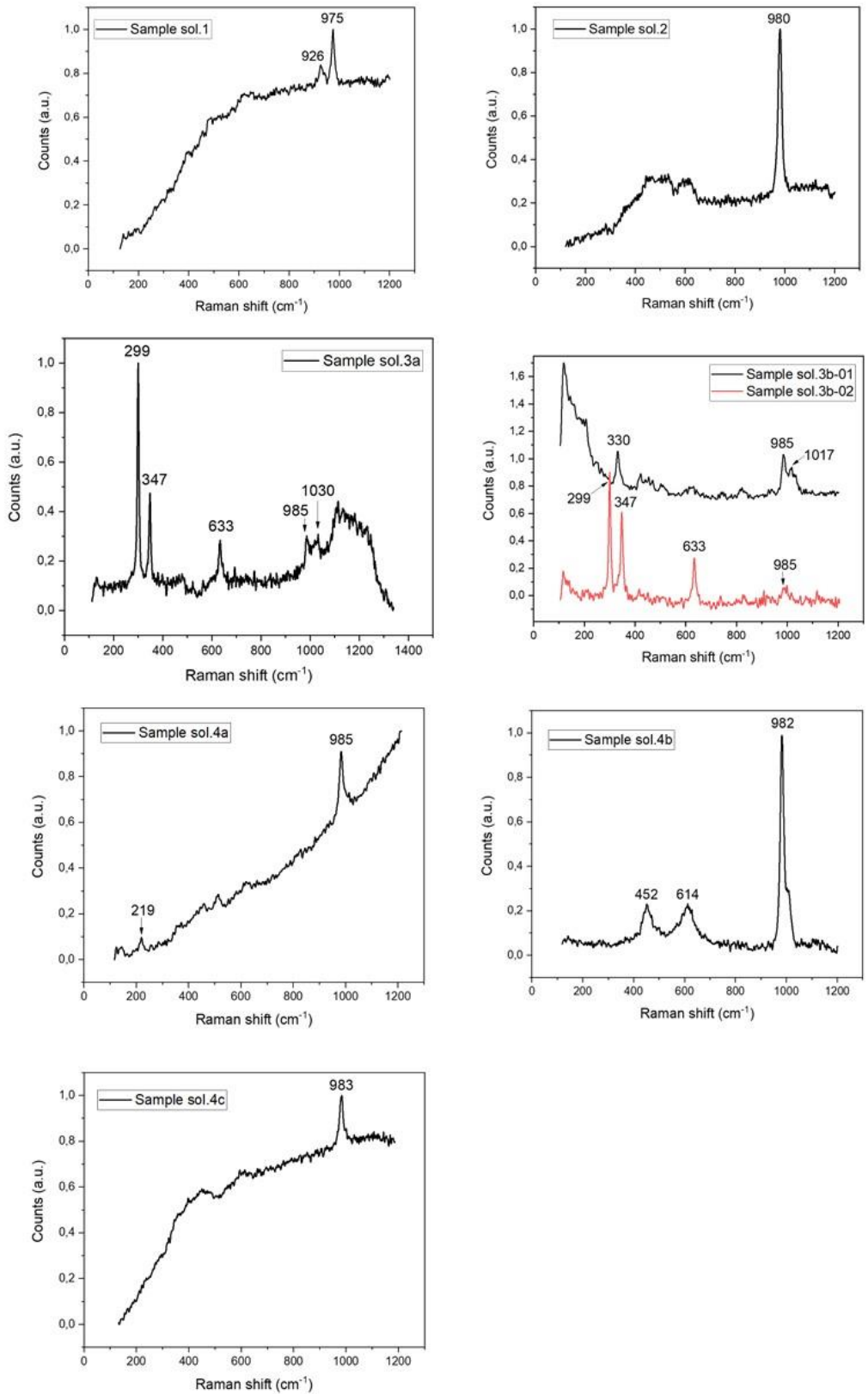

Figure 6: Raman spectra of the copper scale after immersion in the different solutions. The presence of alum was determined thanks to the peak between 970 and $985 \mathrm{~cm}^{-1}$.

Sample 5 was not analyzed because, after 7 days of immersion in the chosen solution, the cuprite powder did not wet at all. We proceed with filtering of the solution and the powder shows the same red color of the original synthetic cuprite. Thus, this experiment is considered as a failure.

\section{Results after experimental melting}


A melting experiment using pre-treatment copper scale (sample $4 \mathrm{~b}$ ) is performed. The melting is not optimal considering that the stirring is not possible considering the type of furnace and the low amount of matter involved $(1.2 \mathrm{~g}) .^{5} \mathrm{~A}$ comparison of the XRF spectra for the melting experiments with and without pre-treated copper scale is shown in Figure 7.

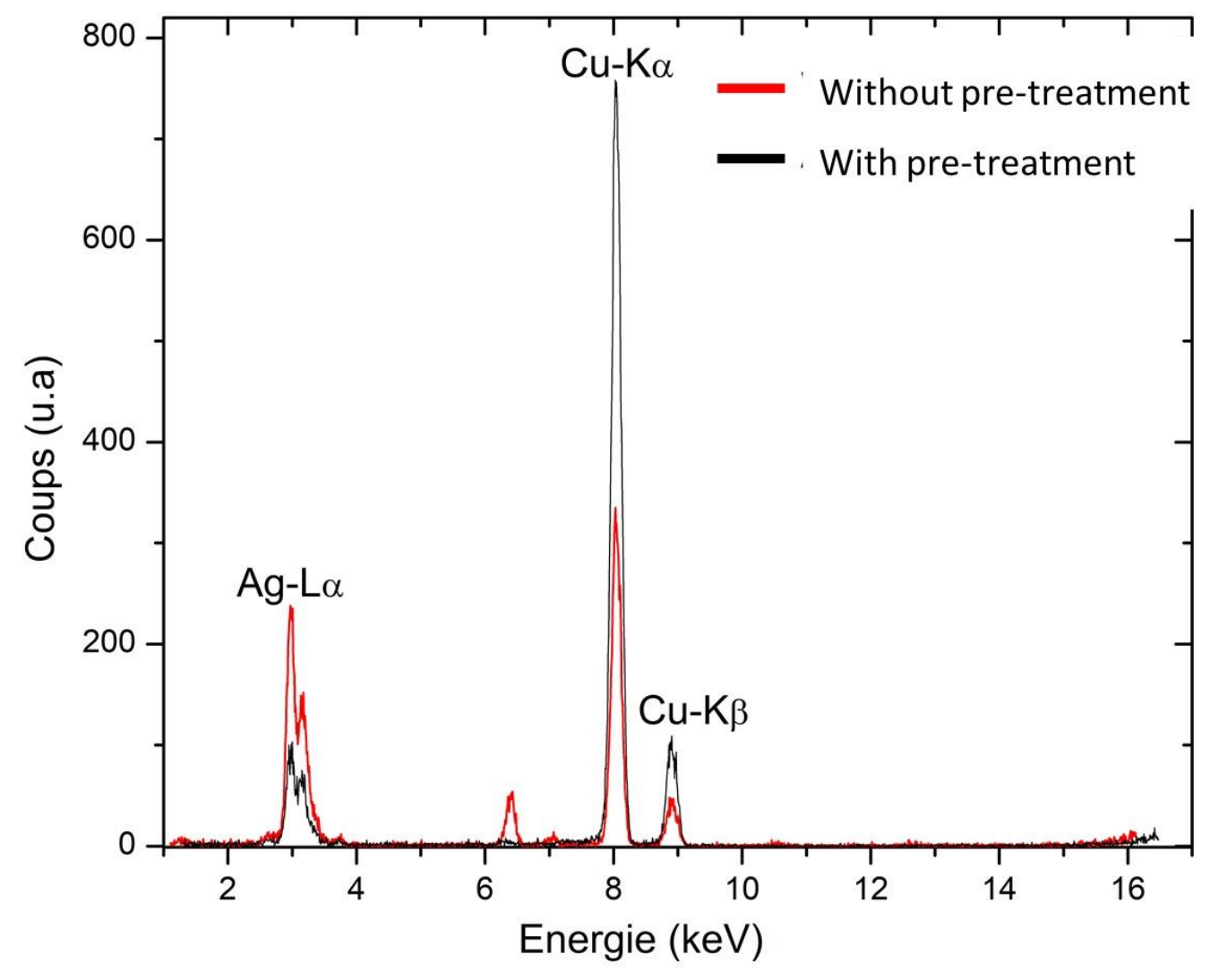

Figure 7: XRF spectra of, in red, the alloy obtained by melting the silver with copper scale (no pre-treatment), and, in black, by melting silver and copper scale pre-treated with alum.

In both cases, the copper scale, with and without pre-treatment, forms an alloy with silver. In the case of the copper scale pre-treated with the salt-alum solution (sample $4 \mathrm{~b}$ ), we observe that the alloying process is more efficient as a larger amount of copper is found in the alloy compared to the not pre-treated scale. The efficiency of the alloying process drastically increases.

\footnotetext{
${ }^{5} \mathrm{We}$ did not investigate further the quality of the alloy formed in this way since the conditions are too far from those of a melting carried out in a historical furnace.
} 


\section{Discussion}

The central aspect of all recipes detailed in the introduction is the color. Reference to the color is found in both steps: first, in the preparation of the copper scale that will be added to silver and, secondly, in the description of the final alloy obtained by the mix of copper scale and silver.

Following the interpretation of R. Halleux, we can assume that the purpose of treating the copper scale with alum is to deceive the client who is assisting to the melting. The goldsmith needs to add the copper scale, which has, without any treatment, a black-to-red color, to the white silver metal. The pre-treatment of the copper scale, as it is described in the texts, leads to a silvery-looking material. This is what is obtained by pre-treating the copper scale with solutions $1,2,4 \mathrm{~b}, 4 \mathrm{c}$ and, to a lesser extent, $4 \mathrm{a}$.

Moreover, it must be kept in mind that the alloy itself will remain silvery-white as long as the mass of copper does not exceed $85 \%$. The title of the recipe ("doubling of silver") can be interpreted as an increase in mass. Therefore, the fraud is possible until $85 \%$ in mass of copper is added. By adding 85 to $92 \%$ in mass of copper, the color of the alloy will shift to a red hue that may arise suspicion, and beyond $92 \%$, the alloy obtained can no longer be mistaken with silver.

Even without taking the term "doubling" literally, adding the right amount of copper scale, will easily allow to deceive the customer.

Moreover, the meaning of the recipes seems not to be related merely to a fraud by a change in color of the raw materials. In fact, as demonstrated by the XRF analysis on the alloy, the amount of copper that can be introduced into the solid solution with silver increases when a pretreatment of the copper scale based on alum is performed. This results in a more efficient process. Therefore, the smith could consider adopting the pre-treatment operations involving the use of alum.

We did not proceed further with the experiment, but it is likely that the alloy can be obtained even in the case of different coloration of the copper scale. These differences highlight two aspects of the treatments that are not mentioned in the text: the importance of rinsing after the 
immersion in solution of the scale and the change in color as a function of the time after immersion. In the case of sol. 4, only drying and rinsing operations allowed to obtain a whitish scale. In parallel, the recipe based on 'Leid 12', the copper scale turns white after the second and last immersion. The intermediate test carried out using only 'sol.2' containing a saturated solution of alum, also leads to white scale but only after several days of exposure to air and without any further operation such as rinsing or drying. Such protocol does not appear in any of the recipes.

A last interesting remark concerns the experiment carried out using synthetic cuprite powder. The composition of the raw material is the same as expected for the copper scale but its reactivity with the solution is different. Such difference could be due to the nanometric grain size of the synthetic powder; the presence of pollutants adsorbed on the surface of the grains derived from the industrial synthesis could also influence the reactivity of the mineral. The failure of such experiment stresses the importance of using materials as similar as possible to those that could be found in ancient times.

\section{Conclusion}

The experimentation carried out leads us to the conclusion that the procedures described in the two recipes have a double meaning. On one side, the operation described turns the black copper scale into a whitish material, more suitable to trick a client who is assisting to the melting of an artefact. In this sense, this family of recipes seems to be part of a workshop practice aiming at deceiving "visually" a customer. The process involving the pre-treatment of the scale using alum can be related to an act of forgery.

On the other side, we demonstrate that it seems possible to melt silver and copper in a more efficient way by adding a copper scale pre-treated with the alum solution. We observe here a case in which recycling of a waste material has a positive effect on the production process. The goldsmith could easily get cheap copper scale from a coppersmith, considering that the scale can be defined as a production waste of the latter.

At the present state, it is not possible to assess whether or how common the process described in the papyri was for the production of silver objects; a regular production of pre-treated scale seems to be difficult to realize on a large-scale production. Nevertheless, the experimentation shows that alum, if employed following a precise procedure, can have a positive effect on the alloying process of silver. 


\section{Acknowledgments}

This work was funded by grants from the the Programme Collectif de Recherche "Paléométallurgie et expérimentations - Recherches sur les chaines de production des métaux aux périodes anciennes" conducted at the Experimental platform at Melle (France).

\section{Bibliography}

Berthelot M., Introduction à l'étude de la chimie des anciens et du moyen âge, Brussels, 1889 Borgard P., Brun J.-P., Picon M. (eds.), L’alun de Méditerranée, Coll. du Centre Jean Bérard, 23, Naples-Aix-en-Provence, 2005

Bouchard M., Smith D. C., Catalogue of 45 reference Raman spectra of minerals concerning research in art history and archaeology, especially in corroded metals and coloured glass, Spectrochim. Acta-Part A Mol. Biomol. Spectrosc., 59, 2003, 2247-2266

Deng Y., Handoko A. D., Du Y., Xi S., Yeo B. S., In situ Raman spectroscopy of copper and copper oxide surfaces during electrochemical oxygen evolution reaction: identification of $\mathrm{Cu}^{\text {II }}$ oxides as catalytically active species, ACS Catalysis, 6, 2016, 2473-2481

Giumlia-Mair A., Alum in ancient metallurgy, in Borgard P., Brun J.-P., Picon M. (eds.), L’alun de Méditerranée, coll. du Centre Jean Bérard, n²3, Naples-Aix-en-Provence, 2005, $335-341$

Halleux R., Le sens d'Asemos dans le papyrus chimique de Leyde et dans l'alchimie grécoégyptienne, Chron Egypte, 48, 96, 1973, 370-380.

Halleux R., Les alchimistes grecs, Papyrus de Leyde, Papyrus de Stockholm, Fragments de recettes, T.1, ed. Les belles lettres, Paris, 1981. An English translation can be found here: http://www.che.uc.edu/jensen/w.\%20b.\%20jensen/Books/Leyden\%20\&\%20Stockholm\%20P apyri.pdf

Kishimura H., Imasu Y., Matsumoto H., Thermal dehydration of potash alum studied by Raman spectroscopy and X-ray diffraction analysis, Materials Chemistry and Physics, 149150, 2015, 99-104.

Solé V. A., Papillon E., Cotte M., Walter Ph., Susini J., A multiplatform code for the analysis of energy-dispersive X-ray fluorescence spectra, Spectrochim. Acta Part B 62, 2007, 63-68. 


\section{List of figures}

Figure 1: Raw materials, from right to left: copper scales, alum and sea salt

Figure 2: Diffraction pattern of the copper scale obtained after heating in the muffle furnace. The scale as it appears after heating (green) and the scale grinded (blue). In red the characteristic signature of cuprite $\left(\mathrm{Cu}_{2} \mathrm{O}\right)$, and in black that of tenorite $(\mathrm{CuO})$.

Figure 3: Raman spectra of the copper scale.

Figure 4: XRD diffraction pattern and X-ray fluorescence spectra of the alum crystal (the peaks of $\mathrm{Cu}, \mathrm{Zn}$ and $\mathrm{Pb}$ are highlighted in the upright panel)

Figure 5: Raman spectra of the alum.

Figure 6: Raman spectra of the scale after immersion in the different solutions.

Figure 7: XRF spectra of, in red, the alloy obtained by melting the silver with copper scale (no pre-treatment) and, in black, by melting silver and copper scale pre-treated with alum. 